\title{
Some Observations on the Formation of an Active Pronival Rampart at Grunehogna Peaks, Western Dronning Maud Land, Antarctica
}

\author{
D.W. Hedding ${ }^{1 *}$, K.I. Meiklejohn², J. Le Roux ${ }^{3}$, M. Loubser ${ }^{2}$, J.K. Davis ${ }^{2}$ \\ ${ }^{1}$ Department of Geography, University of South Africa, Florida, 1710, South Africa \\ ${ }^{2}$ Department of Geography, Geoinformatics and Meteorology, University of Pretoria, \\ Pretoria, 0002, South Africa \\ ${ }^{3}$ Agricultural Research Council, Pretoria, 0002, South Africa \\ Submission to: Permafrost and Periglacial Processes
}

Date: $\quad 23$ October 2009

Figures: $\quad 4$

Table: $\quad 3$

Abstract: $\quad 197$

Words: $\quad 3037$ (text only: 2243)

${ }^{*}$ Address for correspondence:

D.W. Hedding

Department of Geography

University of South Africa (Florida Campus)

Florida

1710

SOUTH AFRICA

\author{
Tel: $\quad+27114712120$ \\ Fax: $\quad+27114713216$ \\ heddidw@unisa.ac.za
}




\title{
Some Observations on the Formation of an Active Pronival Rampart at Grunehogna Peaks, Western Dronning Maud Land, Antarctica
}

\begin{abstract}
Downslope extension of pronival (protalus) ramparts has been proposed to occur at the foot of thickening snowbeds or firn fields. A suggested morphological characteristic of such landforms is that the distal slope is formed at repose $\left(34-38^{\circ}\right)$ by the accumulation of cohesionless cascading debris. However, data on rampart morphology and debris accumulation, in terms of locality of deposition, of an actively-forming pronival rampart at Grunehogna Peaks, Western Dronning Maud Land, Antarctica demonstrates that, although rockfall debris accumulation indicates downslope (outward) rampart extension, this landform does not possess a distal slope at repose. In addition, observations from the austral summers of 2006/7 and 2008/9 suggest that the firn field size is stable. The aim of this paper is to demonstrate that the morphological characteristics and environmental conditions under which pronival ramparts develop according to the model of downslope extension may be more varied than originally thought. Moreover, this paper questions the use of the morphology of fossil features to infer rampart formation and highlights that caution should be used when using pronival ramparts in palaeo-environmental reconstructions.
\end{abstract}

Key Words: Pronival rampart; protalus rampart; Antarctica; debirs transport; firn field 


\section{Introduction}

A pronival rampart is a ridge or ramp of debris formed at the downslope margin of a snowbed or firn field (Shakesby, 1997). In English literature, these features were commonly known as protalus ramparts (e.g. Bryan, 1934; Ballantyne \& Kirkbride, 1986; Ballantyne, 1987) but Shakesby (1997) has recently proposed the replacement of 'protalus' with 'pronival' since the latter provides a universally appropriate term that describes the position of ramparts at the foot of snowbeds or firn fields; regardless of their position on the slope. Curry et al. (2001) indicate that various rampart origins exist (i.e. glacial, rampart, rockslide and protalus rock glacier) and studies (e.g. Harris, 1986; Ono \& Watanabe, 1986; Ballantyne, 1987; Shakesby, 1995; 1999) have shown that an appreciable range of supranival and subnival mechanisms of debris transport may contribute to rampart development. It is pertinent to point out that only supranival mechanisms of debris transport are discussed in this paper. Ramparts formed through supranival debris transport mechanisms accumulate partly through debris cascading down and piling up on the distal slope, and partly by entrapment of moving debris against the proximal slope (Ballantyne, 1987; Pérez, 1988). However, Shakesby (1997) emphasises that relatively little research has been conducted on actively accumulating pronival ramparts and Anderson et al. (2001) indicate that research on their formation is particularly limited since it has, in the past, typically been assumed or inferred (Ballantyne, 1987).

Two models of rampart development, through supranival debris transport and deposition, have hitherto been proposed. These include the downslope (outward) model of Ballantyne \& Kirkbride (1986) and the retrogressive (upslope) model of Hedding et al. (2007). The downslope model of rampart development of Ballantyne \& Kirkbride (1986) proposes downslope rampart extension at the foot of thickening snowbeds. A suggested morphological characteristic of ramparts which extend 
downslope is that the distal slope is formed at repose $\left(34-38^{\circ}\right)$ by the accumulation of cohesionless cascading debris. However, not all ramparts exhibit a distal slope which is at repose and led Hedding et al. (2007) to propose a retrogressive (upslope) model of rampart development which envisages retrogressive development under fluctuating, and possibly declining, snowbed volumes. Thus, depending on which of the existing models of rampart development fit a feature, very different palaeo-environmental conditions can be inferred. This paper aims to assess the formation of an activelyforming pronival rampart at Grunehogna Peaks, Western Dronning Maud Land, Antarctica against these existing models of supranival rampart development. Data on rampart morphology, observations of the associated firn field size from the austral summers of 2006/7 and 2008/9 and debris accumulation, in terms of locality of deposition, are described. This data indicates that the morphology and environmental conditions under which pronival ramparts extend downslope (outward) may be more varied than originally thought. The data are then also used to question the use of the morphology of fossil features to infer rampart formation as well as stress that caution should be employed when using fossil pronival ramparts in palaeo-environmental reconstructions.

\section{Environmental Setting and Study Site}

The pronival rampart $\left(72^{\circ} 03^{\prime} 13^{\prime \prime} \mathrm{S} ; 2^{\circ} 42^{\prime} 47^{\prime \prime} \mathrm{W}\right)$ is located at approximately $1090 \mathrm{~m}$ a.s.I. on the north-eastern periphery of the Grunehogna Peaks, a group of nunataks some $200 \mathrm{~km}$ inland of the Southern Ocean (ice-shelf front), at the southern end of the Ahlmannryggen (range), Western Dronning Maud Land, Antarctica (Fig. 1). Geologically, these nunataks are mostly comprised of Borgmassivet intrusives, which are of Precambrian age and have, in some places, undergone some metamorphosism. Nunataks provide ice-free areas where geomorphological processes (apart from 
glacial) can operate, small biological communities can survive and, in some cases, even act as breeding sites for birds, notably snow petrels (Pagodroma nivea) (Ryan et al., 1989). Although no detailed meteorological data exists for Grunehogna Peaks itself, meteorological data between 2000 and 2006 for the South African Base (SANAE IV) atop the Vesleskarvet nunatak (7140'22”S; $\left.2^{\circ} 50^{\prime} 25^{\prime \prime} \mathrm{W}\right)$, approximately $50 \mathrm{~km}$ farther north, at $845 \mathrm{~m}$ a.s.I. give a mean annual air temperature of $-17^{\circ} \mathrm{C}$. The mean winter air temperature is $-21.7^{\circ} \mathrm{C}$ while the mean summer air temperature is $-10.8^{\circ} \mathrm{C}$.

Most nunataks in this region of Antarctica exhibit wind-scoured hollows in the leeward side of the prevailing wind direction where debris can accumulate and geomorphological processes can operate without being destroyed by glacial erosion. The pronival rampart is situated within such a wind-scoured hollow and can be found below a precipitous (approximately $120 \mathrm{~m}$ high) backwall at the foot of a perennial firn field where there is a marked reduction in gradient (Fig. 2). The rampart incorporates some intermittent interstitial fines but comprises predominantly openwork clastic material (long axis $<0.5 \mathrm{~m}$ ) that is made up solely of Borgmassivet intrusives which is the same lithology as the backwall. The rampart faces north-west and exhibits a sinuous 'crest' (Fig. 3). From visual observations during field visits during the austral summers of $2006 / 7$ and $2008 / 9$ the firn field size appears to be stable.

\section{Morphological Measurements}

The "diagnostic criteria" suggested by Shakesby (1997) and tabulated by Hedding et al. (2007) were used to identify the talus landform under investigation as a pronival rampart as well as identify its origin (Table 1). A (transverse) profile along the rampart firn field boundary and four longitudinal transects were surveyed to determine the width (down-slope) (w), length (across-slope) (I) and general surface morphology of the 
rampart and firn field (Fig. 3). Other morphological attributes measured in the field were: the distance from rampart and firn field boundary to the foot of the cliff (d) and angle of snow slope $(\alpha)$. The data of the morphology of the pronival rampart is summarised in Table 2. The four longitudinal transects and spot angles were then used to determine the cross-profile form of the firn field (Fig. 3). The average firn field angle is $34^{\circ}$ and the mean distance from rampart crest to foot of the backwall is $24 \mathrm{~m}$, which falls below the suggested threshold value of $25-40 \mathrm{~m}$ of transition from stationary firn to a dynamic, small glacier for an average firn field angle of $35^{\circ}$ (Ballantyne \& Benn, 1994). All firn field angles are larger than the minimum value of $20^{\circ}$, required for debris movement over firn as identified by Ballantyne \& Benn (1994). The length (acrossslope) (I) of the rampart is $85 \mathrm{~m}$ and the width (down-slope) (w) is, on average, $23 \mathrm{~m}$ from the rampart-firn field boundary to the foot of the distal slope. The average slope angles of the proximal and distal slopes are $14^{\circ}$ and $20^{\circ}$ respectively.

\section{Debris Transport and Deposition}

Debris transport and accumulation was tested by releasing fifty clasts from approximately $5 \mathrm{~m}$ from the top of the firn field (Fig. 4). It was impossible to conduct the debris transport experiment from the top of the backwall above the rampart due to the inaccessibility of this area. It was also impossible to climb to the top of the firn field due to the steep (approximately $50^{\circ}$ ) and hard firn in this upper section. Only relatively small angular clasts were used $(<25 \mathrm{~kg})$ and, although clasts were released with far less potential energy than rockfall debris supplied from the backwall above, only two (4\%) of the clasts did not have enough momentum to reach the foot of the firn field.

Clasts travelled down the firn field by rolling, bouncing and gliding, as similarly observed by Pérez (1988), thus confirming supranival debris transport as the mechanism for the delivery of material for rampart formation. No evidence for debris 
from snow avalanches was observed. Only two clasts (4\%) came to rest on the firn field and these clasts later melted into the snow and ice through black-body radiation and may, as is noted by Behre, (1933) and Ono \& Watanabe (1986), melt their way downslope; contributing debris to the rampart. Nineteen (38\%) and fifteen (30\%) of the clasts came to rest on the proximal slope and distal slope, respectively. A further fourteen clasts (28\%) overshot the rampart and came to rest below the rampart; making it difficult to identify a clear downslope margin for the pronival rampart. In summary, $58 \%$ of the clasts released down the firn field surmounted the rampart 'crest' between the proximal and distal slopes. The results are summarised below in Table 3 .

\section{Discussion}

According to the "diagnostic criteria" for pronival ramparts recently tabulated by Hedding et al. (2007), the lack of striated clasts and glacial erosional forms negate a glacial origin. Although the feature exhibits a partial debris apron below it, the lack of a hillslope scar and large masses of displaced hillside within or above the area of debris accumulation discount a landslide origin. The lack of multiple ridges, crenulate or lobate plan form of the outer margins and a greater across-slope distance than downslope distance prevent the feature from being interpreted as a protalus rock glacier. Thus, a wholly pronival rampart origin is deemed valid due to the landform's talus foot location, the backwall and feature being composed of the same lithology (i.e. Borgmassivet intrusives), the feature having a rampart crest to talus-foot distance of less than c.30-70m as well as the confirmation of supranvial debris transport. Interestingly, the feature appears relatively small in relation to the source of debris and this may indicate that the feature is relatively 'young' or that debris production from the backwall is particularly slow. During aerial surveys, similar features were noted at other nunataks (e.g. Jekselen) and, thus, in addition to corrie floors and the flanks of glacial 
troughs, wind-scoured hollows around nunutaks may represent preferential locations for pronival rampart development.

Only $58 \%$ of the clasts released down the firn field surmounted the rampart 'crest', but this is probably due to the limited potential energy with which they were released and a greater percentage of rockfall debris from the backwall is, thus, expected to surmount the rampart 'crest' under natural debris transport. Assessment of the locality of debris deposition indicates that this rampart is extending downslope through supranival debris transport, following the model proposed by Ballantyne \& Kirkbride (1986). An important exception is that distal slope of this rampart is not at repose, which implies that ramparts extending downslope may not necessarily require a distal slope at repose. In addition, the observation of the apparently stable size of the firn field questions the necessity for the continuous growth of a snowbed or firn field for the downslope extension of ramparts. Therefore, rampart morphology and the environmental conditions under which ramparts extend downslope may be more varied than originally thought. This observation indicates that caution should be employed when using the morphology of pronival ramparts in palaeo-environmental reconstructions.

It is pertinent to highlight that ramparts extending downslope on a shallow underlying slope angle under stable snowbed or firn field conditions will only continue to do so as long as the majority of clasts have enough kinetic energy to surmount the rampart 'crest'. However, should the firn field 'grow' through increased snow accumulation the basal shear stress will be increased, encouraging creep of ice and basal sliding, and thus cause the transformation of stationary firn field into a small glacier with the consequent destruction or modification of the rampart (Ballantyne \& Benn, 1994). The self-limiting concept of rampart formation proposed by Ballantyne \& Benn (1994) indicates indicate that beyond a certain size there is a transformation of stationary firn 
into a smaller glacier which can modify or destroy the original landform (Hall \& Meiklejohn, 1997). Threshold values suggested by Ballantyne \& Benn (1994), applicable to the rampart under investigation, indicate that for a snow slope angle of $35^{\circ}$ and assuming the density of the firn field is $800 \mathrm{~kg} / \mathrm{m}^{3}$ the transition from stationary firn into a dynamic, small glacier will take place between $25-40 \mathrm{~m}$. The average snow slope angle is $34^{\circ}$ and the horizontal distance from the rampart 'crest' to backwall is $24 \mathrm{~m}$, which indicates that, at present, the firn field is stationary and the rampart is extending downslope without being destroyed or modified. This illustrates that ramparts are part of a continuum of talus-derived landforms (Shakesby, 1997) but also that periglacial features may be periglacial only in origin, growth, maintenance, or it may be periglacial throughout its development (Thorn, 1992).

\section{Conclusion}

The pronival rampart on the north-eastern periphery of the Grunehogna Peaks, Western Dronning Maud Land represents the first pronival rampart to be documented in detail for the Antarctic. Data on rampart morphology and debris accumulation, in terms of locality of deposition, indicates downslope rampart extension. However, this landform does not possess a distal slope at repose. Observations from the austral summers of $2006 / 7$ and $2008 / 9$ suggest that the firn field size is stable and stationary, at present, based on the threshold values for ice movement proposed by Ballantyne \& Benn (1994). Collectively, these findings indicate that the morphological characteristics of and environmental conditions under which the downslope extension of ramparts occur may be more varied than originally thought. In addition, this paper questions the use of the morphology of fossil features to infer rampart formation. Shakesby (1997) advocates that future studies on pronival ramparts should be centred on activelyforming features but the re-investigation of questionable but documented 'pronival ramparts' (e.g. Gordon \& Ballantyne, 2006) as well as examination of described but 
undocumented rampart-like features such as the rampart-like ridge briefly described by Selkirk et al. (2008) for sub-Antarctic Macquarie Island could provide some useful insights in the formation of pronival ramparts.

\section{Acknowledgements}

The Department of Environmental Affairs and Tourism and the National Research Foundation are gratefully acknowledged for logistical and financial support. Franz Hoffman, Dr Jennifer Lee, Dr Ross Hofmeyer and Lötter Kock are thanked for assistance and company in the field.

\section{References}

Ballantyne CK. 1987. Some observations on the morphology and sedimentology of two active protalus ramparts, Lyngen, northern Norway. Arctic and Alpine Research 19: 167-174.

Ballantyne CK. and Kirkbride MP. 1986. The characteristics and significance of some lateglacial protalus ramparts in Upland Britain. Earth Surface Processes and Landforms 11: 659-671.

Ballantyne CK. and Benn DI. 1994. Glaciological constraints on protalus rampart development. Permafrost and Periglacial Processes 5: 145-153.

Berhe CH. 1933. Talus behaviour above timber in the Rocky Mountains. Journal of Geology 41: $622-635$.

Curry AM., Walden J. and Cheshire A. 2001. The Nant Ffrancon 'protalus rampart': evidence for Late Pleistocene paraglacial landsliding in Snowdonia, Wales. Proceedings of the Geologists' Association 112: 317-330. 
Gordon LS. and Ballantyne CK. 2006. 'Protalus Ramparts' on Navajo Mountain, Utah, USA: Reinterpretation as Blockslope-sourced Rock Glaciers. Permafrost and Periglacial Processes 17: $179-187$.

Harris C. 1986. Some observations concerning the morphology and sedimentology of a protalus rampart, Okstindan, Norway. Earth Surface Processes and Landforms 11: 673-676.

Hedding DW., Sumner PD., Holness SD. and Meiklejohn KI. 2007. Formation of a pronival rampart on sub-Antarctic Marion Island. Antarctic Science 19: 443-450.

Ono Y. and Watanabe T. 1986. A protalus rampart related to alpine debris flows in the Kuranosuke Cirque, northern Japanese Alps. Geografiska Annaler 86A: 213-223.

Pérez FL. 1988. Debris transport over snow surfaces: a field experiment. Revue de Géomorphologie Dynamique 37: 81-101.

Ryan PG., Watkins BP., Lewis Smith RI., Dastych H., Eicker A., Foissner W., Heatwole H., Miller, W.R. and Thompson G. 1989. Biological survey of Robertskollen, western Dronning Maud Land: area description and preliminary species list. South African Journal of Antarctic Research 19: 10-20.

Shakesby RA. 1997. Pronival (protalus) ramparts: a review of forms, processes, diagnostic criteria and palaeoenvironmental implications. Progress in Physical Geography 21: 394-418.

Shakesby RA., Matthews JA. and McCarroll, D. 1995. Pronival ('protalus') ramparts in the Romsdalsalpane, southern Norway: forms, terms, subnival processes, and alternative mechanisms of formation. Arctic and Alpine Research 27: 271-282. 
Shakesby RA., Matthews JA., McEwan LJ. and Berrisford MS. 1999. Snow-push processes in pronival (protalus) rampart formation: geomorphological evidence from Smørbotn, Romsdalsalpane, Southern Norway. Geografiska Annaler 81A: 31-45.

Selkirk PM., Seppelt RD. and Selkirk D. 2008. Subantarctic Macquarie Island: Environment and Biology. Cambridge University Press. pp 300.

Thorn CE. 1992. "Periglacial geomorphology: what, where, when?". In Dixon JC. and Abrahams AD. (eds). Periglacial Geomorphology, Wiley, 1-30. 
Table 1: Diagnostic criteria for distinguishing a pronival (protalus) rampart from other talus landforms (Adapted from Hedding et al., 2007).

\begin{tabular}{|c|c|c|}
\hline Criteria & & $\begin{array}{l}\text { Additional } \\
\text { Comments }\end{array}$ \\
\hline \multicolumn{3}{|l|}{ Glacier } \\
\hline - Talus-foot location & $\checkmark$ & \\
\hline - Glacial erosional forms & $x$ & \\
\hline - Striated clasts & $\mathrm{x}$ & \\
\hline - Linear plan form & $\checkmark$ & Sinuous \\
\hline - Asymmetrical cross-profile & $\checkmark$ & \\
\hline - Symmetrical cross-profile & $\mathrm{x}$ & \\
\hline - Clasts dip away from backwall & $\mathrm{x}$ & \\
\hline - Ridge crest to cliff-foot distance $>c .30-70 m$ & $x$ & \\
\hline \multicolumn{3}{|l|}{ Landslide } \\
\hline $\begin{array}{ll}\text { - } & \text { Talus-foot location } \\
\text { - } & \text { Hillslone scar }\end{array}$ & v & \\
\hline - Debris aprons beyond the feature & $\checkmark$ & Partial \\
\hline $\begin{array}{l}\text { - Large masses of displaced hillside within or above the area } \\
\text { of debris accumulation }\end{array}$ & $x$ & \\
\hline \multicolumn{3}{|l|}{ Protalus Rock Glacier } \\
\hline - Talus-foot location & $\checkmark$ & \\
\hline - Multiple arcuate ridges & $x$ & \\
\hline - Greater in length (down-slope) than in width (across-slope) & $x$ & \\
\hline - Crenulate or lobate plan form of the outer margins & $\mathrm{x}$ & \\
\hline - Convex distal slope & $\mathrm{x}$ & Rectilinear \\
\hline $\begin{array}{l}\text { - Meandering and closed depressions, downslope ridges and } \\
\text { furrows, and transverse ridges and depressions }\end{array}$ & $x$ & \\
\hline
\end{tabular}

\section{Pronival (Protalus) Rampart}

- Talus-foot location

- Large ridge to backwall summit inclination

- Small ridge to backwall distance

- Ridge crest to cliff-foot distance <c.30-70m

- Restricted potential snow accumulation depth

- Length $<300 \mathrm{~m}$

- Openwork fabric with/without infilling fines

- Single ridge

- Ridge size increase with distance from cliff foot

- Backwall and ridge same lithology

- Angular clasts 
Table 2: Dimensions and morphology of rampart.

\begin{tabular}{|c|c|c|c|c|c|c|c|c|c|c|c|c|}
\hline \multirow[t]{2}{*}{ Type } & \multirow[t]{2}{*}{$\begin{array}{l}\text { Length } \\
\text { (m) }\end{array}$} & \multirow[t]{2}{*}{$\begin{array}{l}\text { Width } \\
\text { (m) }\end{array}$} & \multirow[t]{2}{*}{$\begin{array}{l}\text { Height } \\
\text { (m) }\end{array}$} & \multicolumn{3}{|c|}{$\begin{array}{c}\text { Snow slope } \\
\left({ }^{\circ}\right)\end{array}$} & \multicolumn{3}{|c|}{$\begin{array}{c}\text { Proximal slope } \\
\left({ }^{\circ}\right)\end{array}$} & \multicolumn{3}{|c|}{$\begin{array}{c}\text { Distal slope } \\
\left({ }^{\circ}\right)\end{array}$} \\
\hline & & & & Min & Mean & Max & Min & Mean & Max & Min & Mean & Max \\
\hline Sinuous & 85 & 23 & 24 & 25 & 34 & 43 & 13 & 14 & 19 & 17 & 20 & 24 \\
\hline
\end{tabular}

Table 3: Summary of locality of debris deposition.

\begin{tabular}{|c|c|}
\hline Position of deposition & $\begin{array}{c}\text { No. of clasts } \\
\text { (sample size } \mathbf{5 0})\end{array}$ \\
\hline Firn field & $2(4 \%)$ \\
\hline Proximal slope & $19(38 \%)$ \\
\hline Distal slope & $15(30 \%)$ \\
\hline Below the rampart & $14(28 \%)$ \\
\hline
\end{tabular}



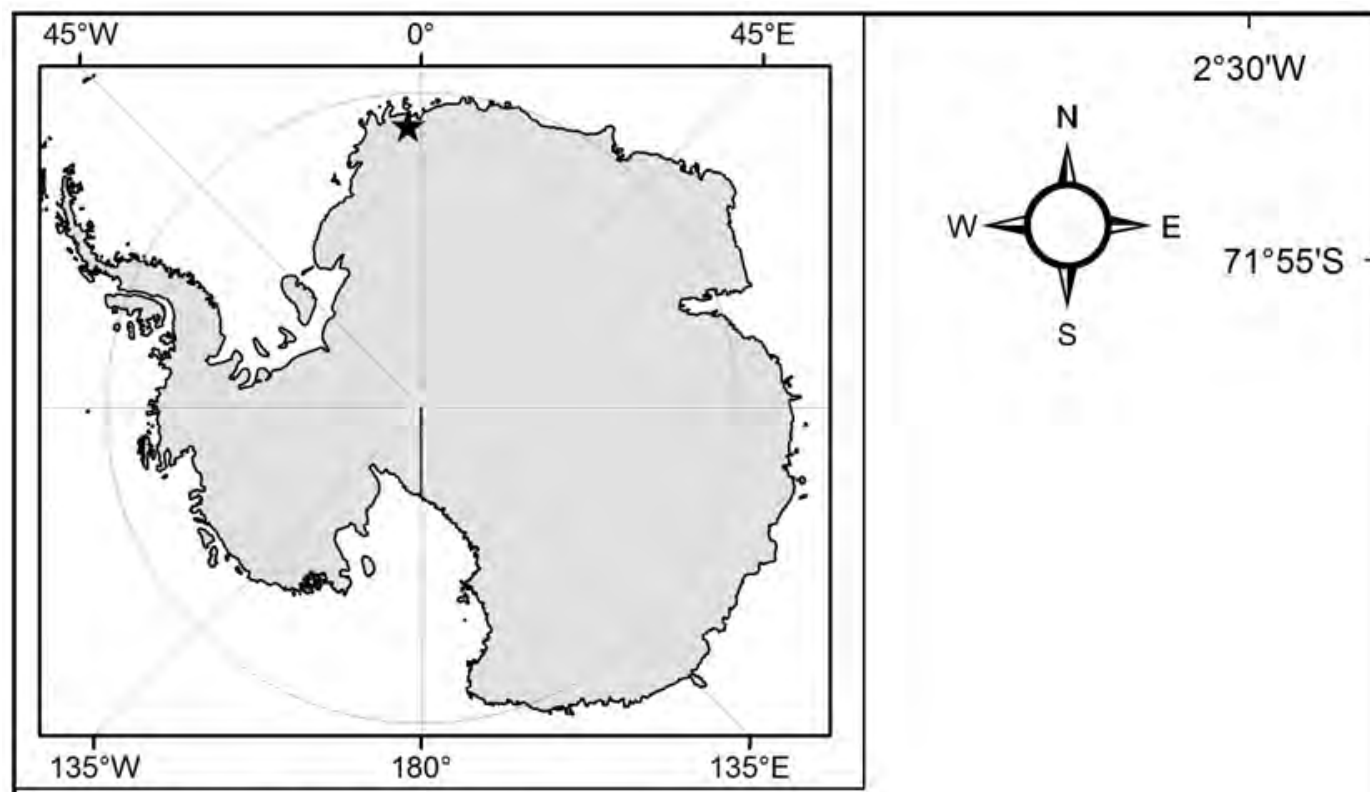

\section{Stereographic Projection}

Datum: WGS 1984
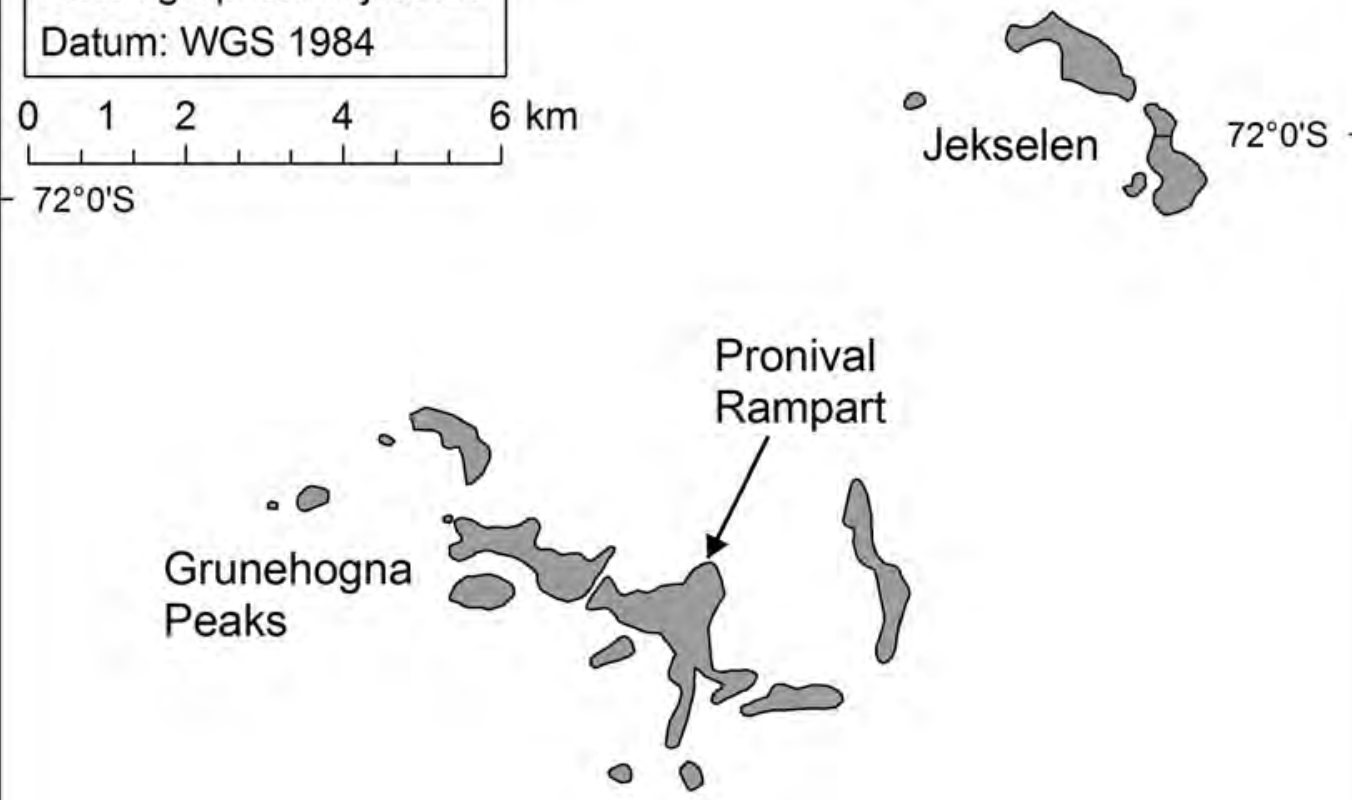

$72^{\circ} 5^{\prime} \mathrm{S}$

$2^{\circ} 50^{\prime} \mathrm{W}$

$2^{\circ} 40^{\prime} \mathrm{W}$

$72^{\circ} 5^{\prime} \mathrm{S}$

$2^{\circ} 30^{\prime} \mathrm{V}$

Figure 1: Location of Grunehogna Peaks in Western Dronning Maud Land, Antarctica and location of the pronival rampart at Grunehogna Peaks. 


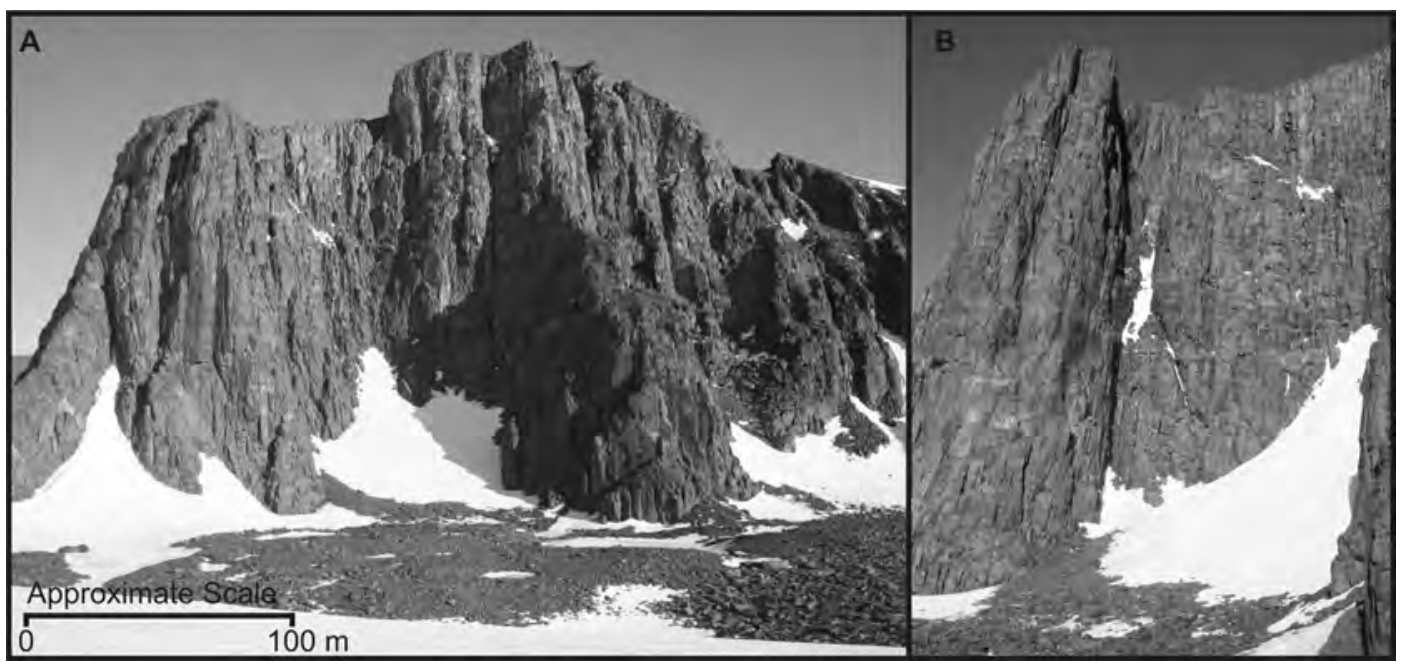

Figure 2: Photo A: View of the pronival rampart, firn field and cliff-face from the north of the feature. The backwall is approximately $120 \mathrm{~m}$ high. Photo B: View of the pronival rampart, firn field and backwall from west of the feature.

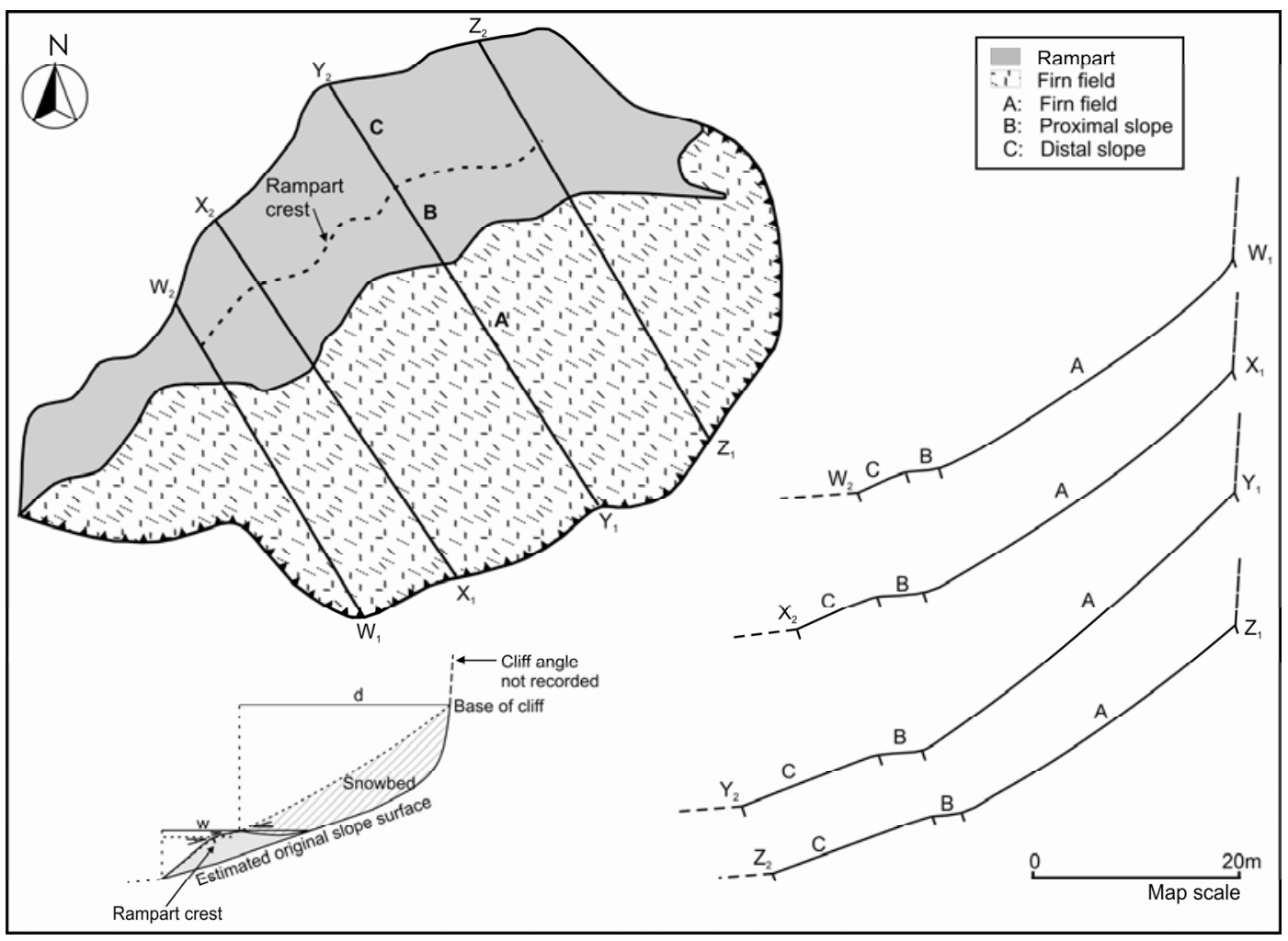

Figure 3: Plan view and surveyed transects of the pronival rampart. 


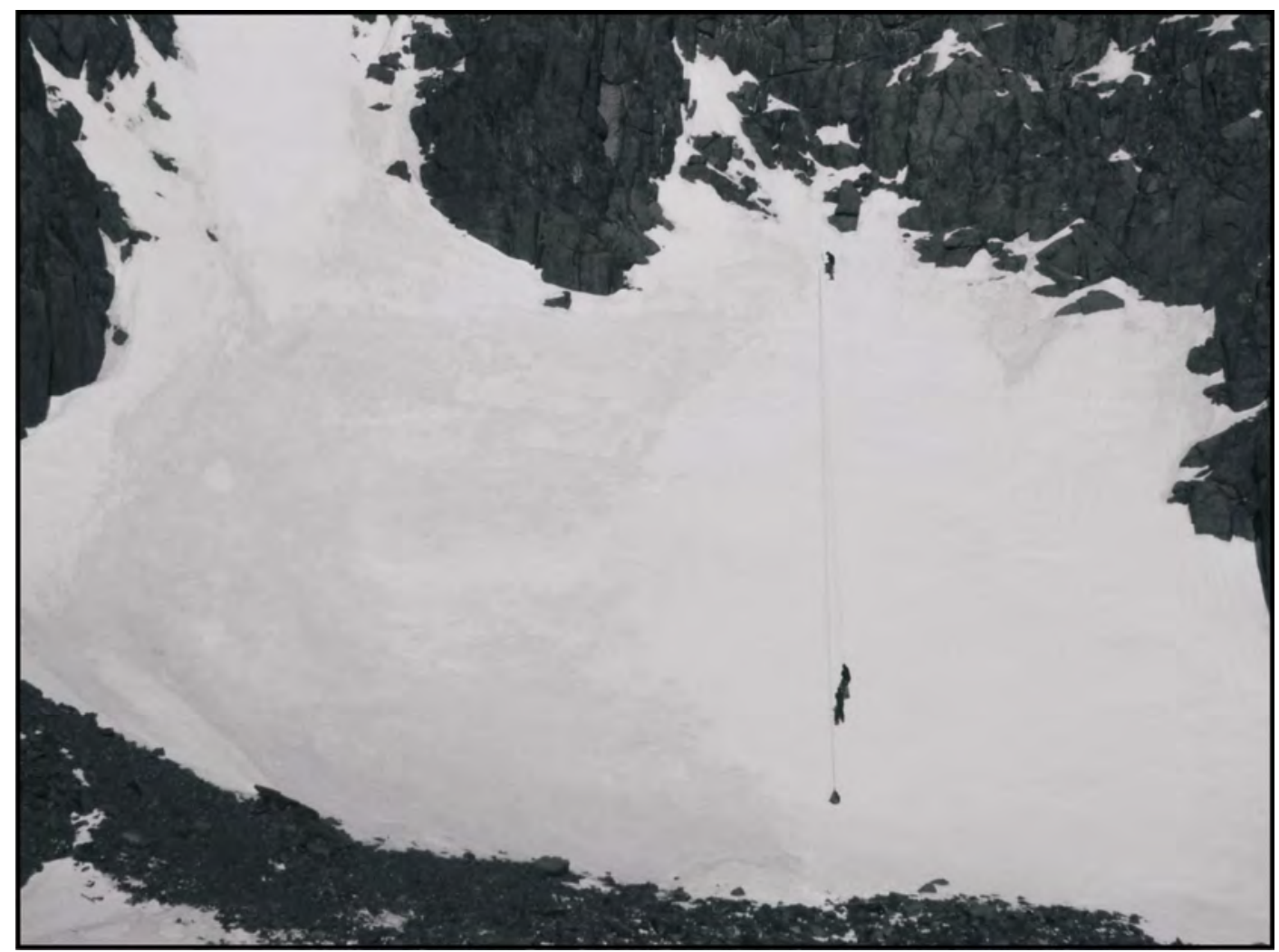

Figure 4: Releasing clasts from approximately $5 \mathrm{~m}$ below the top of the firn field. Note the firn (ice) was hard enough to use crampons. Note the people for scale. 